\title{
EFEKTIVITAS PUPUK HAYATI CAIR DAN PEMANGKASAN DAUN TERHADAP PRODUKSI OKRA (Abelmoschus esculentus L. Moench)
}

\author{
The Effectiveness Of Liquid Biofertilizer And Leaf Pruning On Okra Production \\ (Abelmoschus esculentus L. Moench) \\ Bejo Suroso, Insan Wijaya dan Vita Rahmawati \\ Prodi Agroteknologi Fakultas Pertanian Universitas Muhammadiyah Jember \\ e-mail : ${ }^{1}$ bejo.suroso@unmuhjember.ac.id, ${ }^{2}$ insan.wijaya@unmuhjember.ac.id, \\ ${ }^{3}$ vitacyril@gmail.com
}

\begin{abstract}
ABSTRAK
Penelitian ini bertujuan untuk mengetahui efektifitas penggunaan interaksi perlakuan konsentrasi pupuk hayati cair dengan umur pemangkasan daun terhadap produksi okra (Abelmoschus esculentus L. Moench). Dilaksanakan di Karangrejo, Sumbersari, Jember pada tanggal 22 Nopember 2017 sampai dengan 12 Maret 2018, disusun menggunakan rancangan acak kelompok dengan dua faktor yaitu konsentrasi pupuk hayati cair dengan umur pemangkasan daun. Hasil penelitian menunjukkan (a) jumlah buah per sampel terbanyak sebesar 63 buah pada interaksi tanpa pupuk hayati cair dan tanpa pemangkasan daun dapat meningkatkan produksi $3 \%$ dan terhadap jumlah buah per petak terbanyak sebesar 677 buah pada interaksi pupuk hayati cair konsentrasi $80 \mathrm{ml} / \mathrm{l}$ air dengan pemangkasan daun umur 73 hst dapat meningkatkan hasil produksi $21 \%$, dan (b) berat buah per petak terbanyak sebesar 4093,67 gram (konversi 16,37 ton/ha) pada interaksi pupuk hayati cair konsentrasi $80 \mathrm{ml} / \mathrm{l}$ air dengan pemangkasan daun umur 73 hst dapat meningkatkan produksi $51 \%$.
\end{abstract}

Kata kunci : Okra, konsentrasi pupuk hayati, pemangkasan daun.

\section{ABSTRACT}

This study aims to determine the effectiveness of the use of interaction treatment of liquid biofertilizer concentration with the age of leaf pruning against the production of okra (Abelmoschus esculentus L. Moench). Conducted in Karangrejo, Sumbersari, Jember on November 22, 2017 to March 12, 2018, it was arranged using a randomized block design with two factors namely the concentration of liquid biofertilizer with the age of leaf pruning. The results showed (a) the highest number of fruits per sample was 63 at interaction without liquid biological fertilizer and without leaf pruning can increase production by $3 \%$ and the highest number of fruits per plot at 677 at the interaction of liquid fertilizer with $80 \mathrm{ml} / \mathrm{l}$ water concentration with 73-year-old leaf pruning can increase the yield of $21 \%$, and (b) the highest fruit weight per plot was 4093.67 grams (conversion of 16.37 tons / ha) at the interaction of biofertilizer concentration of $80 \mathrm{ml} / \mathrm{l}$ of water with 73-year-old leaf pruning can increase production by $51 \%$.

Keywords: Okra, biofertilizer concentration, leaf pruning. 


\section{PENDAHULUAN}

Kebutuhan akan makanan bergizi semakin meningkat. Sayuran sebagai bagian integral dari hortikultura merupakan bahan yang mengandung vitamin,mineral, protein, dan sumber kalori yang dibutuhkan oleh manusia. Budidaya sayuran secara optimal merupakan tuntutan pokok yang penting. Salah satu jenis sayuran yang mempunyai prospek ke depan di Indonesia adalah tanaman okra.

Okra (Abelmochus esculentus L. Moench) merupakan salah satu komoditas sayuran yang diproduksi di Kenya terutama untuk pasar ekspor ke Uni Eropa. Namun, produksi tanaman telah dibatasi umur simpan pendek polongnya. Hilangnya polong okra kualitas ditandai dengan menghitam, layu, dan membusuk dalam waktu dua hari dalam kondisi ruang yang menjadikan kerugian pasca panen berat. Untuk mengurangi kerugian, pedagang menggunakan disinfektan agar produk segar tidak mengalami kerusakan dengan menggunakan larutan klorin. Namun, klor memiliki bau yang tidak menyenangkan dan mudah menguap. Selain itu, ada kekhawatiran konsumen yang berkembang pada penggunaan bahan kimia untuk mengelola infeksi (Salunkhe dan Desai, 1984). Telah ada gerakan yang kuat terhadap penggunaan metode tidak berbahan kimia, seperti kemasan dan suhu penyimpanan yang tepat dalam mengelola patogen pascapanen (Bauchmann dan Earles, 2000).

Pupuk hayati mengandung mikroorganisme yang unggul dan bermanfaat terhadap peningkatan kesuburan tanah sebagai hasil proses biokimia tanah. Komposisi pupuk hayati tersebut antara lain adalah (1) Azotobacter sp, berperan sebagai penambat nitrogen, (2) Azospirillum sp, berperan sebagai penambat nitrogen, (3) Bacillus sp, berperan dalam dekomposisi bahan organik, (4) Pseudomonas sp, berperan dalam dekomposisi residu pestisida, dan (5) Cytophaga sp, berperan dalam proses dekomposisi bahan organik..Pupuk hayati juga mengandung hormon pertumbuhan alami seperti giberellin, sitokinin,kinetin, zeatin, dan auksin.Pupuk hayati selain dapat memperbaiki sifat fisik, kimia, dan biologi tanah, juga membantu meningkatkan produksi tanaman, meningkatkan kualitas produk tanaman, mengurangi penggunaan pupuk an-organik dan sebagai alternatif pengganti pupuk kandang (Parman,2007; Manuhuut, 2014).

Pemangkasan merupakan tindakan budidaya yang umum dilakukan untuk mengatasi adanya pertumbuhan vegetatif yang berlebihan pada tanaman. Pemangkasan tanaman ada dua macam, yaitu pemangkasan untuk memilih batang produksi dan pemangkasan pemeliharaan. Pemangkasan produksi perlu dilakukan agar tanaman dapat berproduksi maksimal dengan melakukan pemilihan batang yang dipelihara, sedangkan pemangkasan pemeliharaan dilakukan dengan memangkas bagian tanaman bagian tanaman yang tidak berguna. Menurut Suwito (1990). Jika daun terlalu lebat, maka harus dilakukan pemangkasan, dengan cara memotong pada daun tanaman dan ditinggalkan (3-4) helai daun saja, dengan perlakuan pemangkasan maka tanaman akan cepat bercabang dan berbuah(Soeb, 2000).

Berdasarkan uraian diatas maka penulis tertarik untuk melakukan penelitian guna mengetahui pengaruh konsentrasi pupuk hayati cair dan pemangkasan daun terhadap produksi okra(Abelmoschus esculentus). 


\section{METODE PENELITIAN}

Penelitian ini dilaksanakan di lahan PT Mitra Tani Duatujuh Jember yang bertempat di Lingkungan Plendu, Kelurahan Karangrejo, Kecamatan Sumbersari, Kabupaten Jember. Dimulai tanggal 22 November 2017 sampai 12 Maret 2018 dengan ketinggian tempat \pm 86 meter di atas permukaan laut (mdpl).

Bahan yang digunakan dalam penelitian ini meliputi : Benih okra varietas Garibar dan Pupuk Hayati cair. Adapun alat yang digunakan dalam penelitian ini yaitu : Hand tractor, sprayer punggung semi otomatis, timba, cangkul, gembor, jangka sorong, neraca digital, gelas ukur, cetok, corong, jurigen, gayung, tali rafia, tugal, gunting pemotong rumput, dan ajir bambu.

Penelitian dilakukan secara faktorial (4 x 4) dengan pola dasar Rancangan Acak Kelompok (RAK) yang terdiri dari dua faktor yaitu faktor pertama Pemberian Konsentrasi Pupuk Hayati Cair (H) dan faktor kedua Perlakuan Perompesan Daun (P) yang masingmasing perlakuan diulang 3 kali.

a) Faktor IKonsentrasiPupuk Hayati Cair, terdiri dari 4 taraf :

$\mathrm{H}_{0}=$ Tanpa Pemberian PHC K-Bioboost

$\mathrm{H}_{1}=40 \mathrm{ml} / \mathrm{lPupuk}$ Hayati Cair K-Bioboost

$\mathrm{H}_{2}=80 \mathrm{ml} / \mathrm{lPupuk}$ Hayati Cair K-Bioboost

$\mathrm{H}_{3}=120 \mathrm{ml} / \mathrm{lPupuk}$ Hayati Cair K-Bioboost

b) Faktor II Perompesan Daun, terdiri dari 4 taraf :

$\mathrm{P}_{0}=$ Tanpa Perompesan Daun

$\mathrm{P}_{1}=$ Perompesan Daun umur 53 hst

$\mathrm{P}_{2}=$ Perompesan Daun umur $73 \mathrm{hst}$

$\mathrm{P}_{3}=$ Perompesan Daun umur 93 hst

c) Kombinasi perlakuan sebagai berikut :

$\begin{array}{llll}\mathrm{H}_{0} \mathrm{P}_{0} & \mathrm{H}_{1} \mathrm{P}_{0} & \mathrm{H}_{2} \mathrm{P}_{0} & \mathrm{H}_{3} \mathrm{P}_{0} \\ \mathrm{H}_{0} \mathrm{P}_{1} & \mathrm{H}_{1} \mathrm{P}_{1} & \mathrm{H}_{2} \mathrm{P}_{1} & \mathrm{H}_{3} \mathrm{P}_{1} \\ \mathrm{H}_{0} \mathrm{P}_{2} & \mathrm{H}_{1} \mathrm{P}_{2} & \mathrm{H}_{2} \mathrm{P}_{2} & \mathrm{H}_{3} \mathrm{P}_{2} \\ \mathrm{H}_{0} \mathrm{P}_{3} & \mathrm{H}_{1} \mathrm{P}_{3} & \mathrm{H}_{2} \mathrm{P}_{3} & \mathrm{H}_{3} \mathrm{P}_{3}\end{array}$

\section{HASIL DAN PEMBAHASAN}

Hasil penelitian tentang Efektivitas Konsentrasi Pupuk Hayati Cair dan Pemangkasan Daun Terhadap Produksi Okra (A.esculentus). Hasil analisis ragam (anova) dari semua variabel pengamatan dapat dilihat pada Tabel 1. 
Agritrop, Vol. 16 (2): 250 - 262

Tabel 1. Rangkuman analisis ragam

\begin{tabular}{lcccccc}
\hline & \multicolumn{5}{c}{ F-Hitung } \\
\cline { 2 - 7 } Variabel Pengamatan & Hayati (H) & & Pemangkasan (P) & \multicolumn{3}{c}{$\begin{array}{c}\text { Interaksi } \\
\text { (HxP) }\end{array}$} \\
\hline Jumlah Buah Sampel & 1,210 & $\mathrm{~ns}$ & 1,140 & $\mathrm{~ns}$ & 0,700 & $\mathrm{~ns}$ \\
Jumlah Buah Petak & 52,410 & $* *$ & 28,190 & $* *$ & 33,860 & $* *$ \\
Berat Buah Sampel & 25,140 & $* *$ & 1,860 & $\mathrm{~ns}$ & 1,100 & $\mathrm{~ns}$ \\
Berat Buah Petak & 1824,600 & $* *$ & 312,520 & $* *$ & 382,770 & $* *$ \\
Panjang Buah Sampel & 9,390 & $* *$ & 0,850 & $\mathrm{~ns}$ & 1,700 & $\mathrm{~ns}$ \\
Berangkasan Kering & 9,510 & $* *$ & 1,090 & $\mathrm{~ns}$ & 4,280 & $* *$ \\
\hline
\end{tabular}

ns: tidak berbeda nyata, $*$ : berbeda nyata, $* *$ : berbeda sangat nyata

\section{Jumlah Buah Per Sampel}

Jumlah buah persampel menunjukkan bahwa faktor pupuk cair hayati $(\mathrm{H})$, faktor pemangkasan daun $(\mathrm{P})$ dan interaksi antara kedua faktor pupuk hayati cair dan pemangkasan daun ( $\mathrm{HxP}$ ) berbeda tidak nyata, adapun jumlah buah persampel yang dipengaruhi oleh pemberian pupuk hayati cair, faktor pemangkasan daun dan interaksi kedua faktor disajikan pada Tabel (2, 3 dan 4$)$.

Tabel 2. Jumlah buah per sampel pada faktor konsentrasi pupuk hayati cair $(\mathrm{H})$

\begin{tabular}{lr}
\hline Konsentrasi Pupuk Hayati Cair & Jumlah Buah Per Sampel \\
\hline H3 (120 ml/l air) & 61,833 a \\
H0 (0 ml/l air) & $61,750 \quad$ a \\
H2 (80 ml/l air) & $61,250 \quad$ b \\
H1 (40 ml/l air) & $61,000 \quad$ b \\
\hline
\end{tabular}

Keterangan : Angka yang diikuti huruf yang sama pada kolom yang sama menunjukkan hasil yang berbeda tidak nyata berdasarkan Uji Duncan pada taraf 5\%.

Jumlah buah okra per sampel yang dipengaruhi oleh konsentrasi pupuk hayati cair pada konsentrasi $120 \mathrm{ml} / \mathrm{l}$ air (H3) cenderung memberikan rata-rata jumlah buah per sampel yang terbanyak dibandingkan dengan konsentrasi lainnya. Pemupukan dapat memberikan unsur yang diperlukan bagi tanaman sehingga tanaman dapat tumbuh subur (Tabel 2). Dwidjosepoetro (1996) menyatakan bahwa suatu tanaman akan tumbuh dengan subur bila semua unsur yang diperlukan oleh tanaman berada dalam jumlah yang cukup serta berada dalam bentuk yang siap diabsorbsi oleh tanaman.

Efektivitas Jumlah buah per sampel :

$$
=\frac{H 3-H 1}{H 3} \times 100 \%=\frac{61,833-61,000}{61,833} \times 100 \%=1,35 \%
$$


Tabel 3. Jumlah buah per sampel pada faktor pemangkasan daun (P)

\begin{tabular}{lr}
\hline Pemangkasan Daun & Jumlah Buah Per Sampel \\
\hline P3 (Pemangkasan daun 93 hst ) & $61,833 \quad$ a \\
P2 (Pemangkasan daun 73 hst) & $61,583 \quad$ ab \\
P1 (Pemangkasan daun 53 hst) & $61,500 \quad$ b \\
P0 (Tanpa Pemangkasan Daun) & $60,917 \quad \mathrm{c}$ \\
\hline
\end{tabular}

Keterangan : Angka yang diikuti huruf yang sama pada kolom yang sama menunjukkan hasil yang berbeda tidak nyata berdasarkan Uji Duncan pada taraf $5 \%$.

Jumlah buah okra per sampel yang dipengaruhi oleh pemangkasan daun pada umur 93 hst (P3) cenderung memberikan rata-rata jumlah buah per sampel yang terbanyak dibandingkan dengan pemangkasan daun lainya, hal tersebut diduga karena daun yang terlalu lebat dan lebar (Tabel 3). Luas daun merupakan tempat berlangsungnya fotosintesis yang akan berpengaruh terhadap fotosintat yang dihasilkan oleh tanaman (Prasetyo, 2004).

Efektivitas jumlah buah per sampel :

$$
=\frac{P 3-P 0}{P 3} \times 100 \%=\frac{61,833-60,917}{61,833} \times 100 \%=1,5 \%
$$

Tabel 4. Jumlah buah per sampel pada faktor interaksi antara konsentrasi pupuk hayati cair dan pemangkasan daun $(\mathrm{HxP})$

\begin{tabular}{|c|c|}
\hline $\begin{array}{l}\text { Kombinasi Perlakuan Konsentrasi Pupuk Hayati Cair dan } \\
\text { Pemangkasan }\end{array}$ & $\begin{array}{l}\text { Jumlah B } \\
\text { Per Sam } \\
\end{array}$ \\
\hline H0P0 (0 ml/l dan tanpa pemangkasan) & 63,000 \\
\hline H3P3 (120 ml/l dan $93 \mathrm{hst})$ & 62,667 \\
\hline H3P2 (120 ml dan 73 hst) & 62,333 \\
\hline H0P3 (0 ml/l dan 93 hst) & 61,667 \\
\hline H2P2 (80 ml dan 73 hst) & 61,667 \\
\hline H2P3 (80 ml/l dan 93 hst) & 61,667 \\
\hline H0P2 (0 ml/l dan 73 hst) & 61,333 \\
\hline H1P3 (40 ml/l dan 93 hst) & 61,333 \\
\hline H3P0 (120ml/l dan tanpa pemangkasan) & 61,333 \\
\hline H0P1 (0 ml/l dan $53 \mathrm{hst})$ & 61,000 \\
\hline H1P0 (40 ml/l dan tanpa pemangkasan) & 61,000 \\
\hline H1P2 (40 ml/l dan 73 hst $)$ & 61,000 \\
\hline H2P1 (80 ml/l dan 53 hst) & 61,000 \\
\hline H3P1 (120 ml/l dan 53 hst) & 61,000 \\
\hline H1P1 (40 ml/l dan 53 hst) & 60,667 \\
\hline H2P0 (80 ml/l dan tanpa pemangkasan) & 60,667 \\
\hline
\end{tabular}

Keterangan : Angka yang diikuti huruf yang sama pada kolom yang sama menunjukkan hasil yang berbeda tidak nyata berdasarkan Uji Duncan pada taraf 5\%.

Jumlah buah okra per sampel yang dipengaruhioleh faktor interaksi antara konsentrasi pupuk cair hayati $0 \mathrm{ml} / \mathrm{l}$ airdengan tanpa pemangkasan daun cenderung 
memberikan hasil terbaik dengan jumlah buah 63 per sampel (Tabel 4).

Efektivitas jumlah buah per sampel :

$$
=\frac{H 0 P 0-H 2 P 0}{H 0 P 0} \times 100 \%=\frac{63,000-60,667}{63,000} \times 100 \%=3 \%
$$

\section{Jumlah Buah Per Petak}

Setelah dilakukan analisis ragam didapatkan jumlah buah per petak menunjukan faktor pupuk hayati cair $(\mathrm{H})$, faktor pemangkasan daun $(\mathrm{P})$, dan faktor interaksi pupuk cair hayati dan pemangkasan daun $(\mathrm{HxP})$ berbeda sangat nyata. Hasil uji lanjut Duncan taraf $5 \%$ dapat dilihat pada Tabel $(5,6$,dan 7$)$.

Tabel 5. Jumlah buah per petak pada faktor konsentrasi pupuk hayati cair (H)

\begin{tabular}{lrl}
\hline Konsentrasi Pupuk Hayati Cair & Jumlah Buah Per petak \\
\hline H2 (80 ml/l air) & $644,500 \quad$ a \\
H1 (40 ml/l air $)$ & $626,000 \quad$ b \\
H3 (120 ml/l air $)$ & $597,833 \quad$ c \\
H0 (0 ml/l air) & $593,583 \quad$ d \\
\hline
\end{tabular}

Keterangan: Angka yang diikuti huruf yang sama pada kolom yang sama menunjukkan hasil yang berbeda tidak nyata berdasarkan Uji Duncan pada taraf $5 \%$.

Jumlah buah per petak pada pengamatan hasil analisis jarak berganda Duncan terhadap faktor pemberian konsentrasi pupuk hayaticair menunjukkan bahwa faktor pemberian pupuk cair hayatipada kontrol (H0), pupuk hayaticairpada konsentrasi40 ml/lair (H1), pupuk hayati cairpada konsentrasi80 ml/1 air(H2), pupuk hayaticair pada konsentrasi120 ml/l air(H3) saling berbeda nyata (Tabel 4).Pada konsentrasi pupuk hayati cair $80 \mathrm{ml} / \mathrm{l}$ air cenderung memberian hasil jumlah buah per petak terbanyak sebanyak 644 buah.

Pemberian pupuk dengan jumlah konsentrasi yang seimbang dapat meningkatkan produktifitas tanaman okra. Haryadi (1991) dalam Nasaruddin dan Lengkong (2002) menyatakan bahwabila ketersediaan unsur hara cukup dan seimbang maka pembelahan selakan berlangsung cepat sehingga tanaman akan tumbuh dan berkembang serta berproduksi secara maksimal, sifat tanah sangat diperlukan untuk menyehatkan tanaman dengan seperti itu dapat meningkatkan produksi suatu tanaman.

Efektivitas jumlah buah per petak :

$$
=\frac{H 2-H 0}{H 2} \times 100 \%=\frac{644,500-593,583}{644,500} \times 100 \%=7 \%
$$

Tabel 6. Jumlah buah per petak pada faktor pemangkasan daun (P)

\begin{tabular}{lr}
\hline Pemangkasan Daun & Jumlah Buah Per Petak \\
\hline P3 (Pemangkasan daun 93 hst) & 633,000 a \\
P2 (Pemangkasan daun 73 hst) & $620,917 \quad \mathrm{~b}$ \\
P1 (Pemangkasan daun 53 hst) & 617,000 c \\
P0 (Tanpa Pemangkasan Daun) & $591,000 \quad$ d \\
\hline
\end{tabular}

Keterangan: Angka yang diikuti huruf yang sama pada kolom yang sama menunjukkan hasil yang berbeda tidak nyata berdasarkan Uji Duncan pada taraf 5\%. 
Jumlah buah per petak pada pengamatan hasil analisis jarak berganda Duncan terhadap perlakuan beberapa umur pemangkasan daun menunjukkan bahwa tanpa pemangkasandaun ( $\mathrm{P} 0$ ), perlakuan pemangkasan daun umur 53 hst (P1), perlakuan pemangkasan daun umur 73 hst (P2), dan perlakuan pemangkasan daun umur 93 hst (P3) saling berbeda nyata (Tabel 6). Pada perlakuan pemangkasan daun 93 hst (P3) cenderung memberikan hasil jumlah buahper petak terbaik dengan jumlah 633 buah.

Efektivitas jumlah buah per petak :

$$
=\frac{P 3-P 0}{P 3} \times 100 \%=\frac{633,000-591,000}{633,000} \times 100 \%=6 \%
$$

Tabel 7. Jumlah buah per petak pada faktor interaksiantara konsentrasi pupuk hayati cair dan pemangkasan daun $(\mathrm{HxP})$.

\begin{tabular}{|c|c|c|}
\hline $\begin{array}{l}\text { Konsentrasi Pupuk Hayati dan } \\
\text { Pemangkasan Daun }\end{array}$ & \multicolumn{2}{|c|}{$\begin{array}{c}\text { Jumlah Buah } \\
\text { Per Petak } \\
\end{array}$} \\
\hline H2P2 (80 ml dan 73 hst) & 676,667 & בa \\
\hline H3P3 (120 ml/l dan 93 hst) & 674,667 & $\mathrm{~b}$ \\
\hline H1P1 (40 ml/l dan 53 hst) & 663,000 & c \\
\hline H2P3 (80 ml/l dan 93 hst) & 653,667 & d \\
\hline H2P1 (80 ml/l dan 53 hst) & 643,667 & $\mathrm{e}$ \\
\hline H1P3 (40 ml/l dan 93 hst) & 632,667 & $\mathrm{f}$ \\
\hline H0P1 (0 ml/1 dan 53 hst $)$ & 627,333 & g \\
\hline H1P2 (40 ml/l dan 73 hst $)$ & 612,000 & $\mathrm{~h}$ \\
\hline H2P0 (80 ml/l dan tanpa pemangkasan) & 604,000 & $\mathrm{i}$ \\
\hline H3P2 (120 ml dan 73 hst) & 598,333 & $\mathrm{j}$ \\
\hline H0P2 (0 ml/l dan $73 \mathrm{hst})$ & 596,667 & $\mathrm{k}$ \\
\hline H1P0 (40 ml/l dan tanpa pemangkasan) & 596,333 & 1 \\
\hline H3P0 (120ml/l dan tanpa pemangkasan) & 584,333 & $\mathrm{~m}$ \\
\hline HOP0 (0 ml/l dan tanpa pemangkasan) & 579,333 & $\mathrm{n}$ \\
\hline H0P3 (0 ml/l dan 93 hst) & 571,000 & o \\
\hline H3P1 (120 ml/l dan 53 hst) & 534,000 & $\mathrm{p}$ \\
\hline
\end{tabular}

Keterangan : Angka yang diikuti huruf yang sama pada kolom yang sama menunjukkan hasil yang berbeda tidak nyata berdasarkan Uji Duncan pada taraf 5\%.

Jumlah buah perpetak paling banyak faktor interaksi pupuk hayati $80 \mathrm{ml} / \mathrm{l}$ air dan pemangkasan daun umur 73 hst (H2P2) yaitu 676 buah dan berbeda nyata dengan semua interaksi, sedangkan jumlah buah terendah pada interaksi pupuk hayati $120 \mathrm{ml} / \mathrm{l}$ air dan pemangkasan daun umur 53hst (H3P1). Pemberian kombinasi pupuk yang tepat dapat meningkatkan jumlah produksi okra ditunjukkan oleh yang terbanyak, pemberian pupuk berlebihan dan kekurangan dapat menurunkan pertumbuhan dan perkembangan tanaman (Tabel 7). Darmawan (1983) menyatakan bahwa ketersediaan menyatakan unsur hara yang cukup dan seimbang akan mempengaruhi metabolisme pada jaringan tanaman, karena proses metabolisme merupakan perombakan unsur-unsur hara dan senyawa organik dalam tubuh tanaman untuk pertumbuhan dan perkembangannya.

Efektivitas jumlah buah per petak :

$$
=\frac{H 2 P 2-H 3 P 1}{H 2 P 2} \times 100 \%=\frac{676,667-534,000}{676,667} \times 100 \%=21 \%
$$




\section{Berat Buah Per Petak}

Berat buah per petak setelah dilakukan analisis ragam menunjukkan hasil yang berbeda sangat nyata pada semua faktor yaitu faktor pupuk hayati $(\mathrm{H})$, faktor pemangkasan daun $(\mathrm{P})$ dan faktor interaksi kedua faktor konsentrasi pupuk hayati cair dan pemangkasan daun (HxP). Hasil Uji Lanjut Duncan pada taraf 5\% dapat dilihat pada Tabel (8, 9 dan 10)

Tabel 8. Berat buah per petak pada faktor konsentrasi pupuk hayati cair $(\mathrm{H})$

\begin{tabular}{lrl}
\hline Konsentrasi Pupuk Hayati Cair & Berat Buah Per Petak $(\mathrm{g})$ \\
\hline H2 (80 ml/l air) & 3867,000 & a \\
H1 (40 ml/l air $)$ & 3744,167 & b \\
H0 (0 ml/l air) & 3601,917 & $\mathrm{c}$ \\
H3 (120 ml/l air $)$ & 3518,333 & d \\
\hline
\end{tabular}

Keterangan : Angka yang diikuti huruf yang sama pada kolom yang sama menunHukkan hasil yang berbeda tidak nyata berdasarkan UHi Duncan pada taraf 5\%.

Efektivitas berat buah per petak :

$$
=\frac{H 2-H 3}{H 2} \times 100 \%=\frac{3867,000-3518,333}{3867,000} \times 100 \%=9 \%
$$

Berat buah perpetak pada konsentrasi pupuk hayati cair $80 \mathrm{ml} / \mathrm{l}$ air (H2) menunjukkan rata-rata berat tertinggi yaitu $3867 \mathrm{~g}$ dan berbeda nyata dengan konsentrasi yang lain sedangkan berat rata-rata terendah pada konsenterasi $120 \mathrm{ml} / \mathrm{l}$ air (H3) menunjukkan berbeda nyata dengan perlakuan yang lain.

Tabel 9. Berat buah per petak pada faktor pemangkasan daun (P)

\begin{tabular}{lrl}
\hline Pemangkasan Daun & Berat Buah Per Petak $(\mathrm{g})$ \\
\hline P2 (Pemangkasan daun 73 hst) & $3795,417 \quad \mathrm{a}$ \\
P3 (Pemangkasan daun 93 hst ) & $3712,333 \quad \mathrm{~b}$ \\
P1 (Pemangkasan daun 53 hst ) & $3678,417 \quad \mathrm{c}$ \\
P0 (Tanpa Pemangkasan) & 3545,250 & $\mathrm{~d}$ \\
\hline
\end{tabular}

Keterangan : Angka yang diikuti huruf yang sama pada kolom yang sama JmenunHukkan hasil yang berbeda tidak nyata berdasarkan Uji Duncan pada taraf 5\%.

Berat buah perpetak (Tabel 9) tertinggi pada perlakuan pemangkasan daun $73 \mathrm{hst}$ (P2) diperoleh seberat 3795,42 $\mathrm{g}$ dan berbeda nyata dengan pemangkasan yang lain untuk berat buah perpetak terendah pada perlakuan pemangkasan daun 93 hst (P3) yaitu 2961,75 g yang berbeda nyata dengan pemangkasan yang lain.

Hal ini dikarenakan tanaman memiliki batas dalam penyerapan hara untuk kebutuhan hidupnya batas tersebut yang menjadi pertanda kekurangan atau tercukupinya unsur yang diperlukan. Pemberian pupuk konsentrasi tinggi sampai batas tertentu akan menyebabkan hasil semakin meningkat, dan pada konsentrasi yang melebihi batas tertentu pula akan menyebabkan hasil menjadi menurun dan juga tanaman akan tumbuh dengan baik apabila unsur hara yang diberikan berada dalam jumlah yang seimbang dan sesuai dengan kebutuhan tanaman (Mappanganro dkk., 2011) 
Efektivitas jerat buah per petak :

$$
=\frac{P 2-P 0}{P 2} \times 100 \%=\frac{3795,417-3545,250}{3795,417} \times 100 \%=6 \%
$$

Berat buah perpetak tertinggi pada interaksi pupuk hayati cair $80 \mathrm{ml} / \mathrm{l}$ air dan pemangkasan daun 73 hst (H2P2) yaitu 4093 gram dan berbeda nyata dengan semua interaksi yang lain (Tabel 9). Konsentrasi interaksi terendah pada pemberian pupuk hayati $120 \mathrm{ml} / \mathrm{l}$ dan pemangkasan daun 73 hst (H3P1) yaitu 3183 gram. Menurut Heddy (2007) bahwa perbedaan kemampuan tanaman dalam memanfaatkan faktor lingkungan akan mempengaruhi kemampuan tanaman melakukan fotosintesis dan produksi tanaman. Pupuk yang diberikan dalam bentuk pupuk organik memiliki kelemahan antara lain terbatasnya ketersediaan unsur $\mathrm{N}, \mathrm{P}, \mathrm{K}$, dan Ca.

Tabel 10. Berat buah per petak pada faktor interaksi antara konsentrasi pupukhayati cair dan pemangkasandaun $(\mathrm{HxP})$

\begin{tabular}{|c|c|c|}
\hline Interaksi Pupuk Hayati Cair dan Pemangkasan Daun & Berat Buah P & er Petak $(\mathrm{g})$ \\
\hline H2P2 (80 ml dan $73 \mathrm{hst})$ & 4093,667 & a \\
\hline H1P1 (40 ml/l dan 53 hst) & 3933,333 & $\mathrm{~b}$ \\
\hline H2P3 (80 ml/l dan 93 hst) & 3863,333 & $\mathrm{c}$ \\
\hline H2P1 (80 ml/l dan 53 hst) & 3818,000 & $\mathrm{~d}$ \\
\hline H1P3 (40 ml/l dan 93 hst) & 3789,000 & e \\
\hline H0P1 (0 ml/l dan 53 hst $)$ & 3779,000 & $\mathrm{f}$ \\
\hline H3P2 (120 ml dan 73 hst) & 3740,333 & $\mathrm{~g}$ \\
\hline H2P0 (80 ml/l dan tanpa pemangkasan) & 3693,000 & $\mathrm{~h}$ \\
\hline H3P3 (120 ml/l dan 93 hst) & 3677,000 & $\mathrm{i}$ \\
\hline H0P2 (0 ml/l dan 73 hst) & 3676,333 & $\mathrm{j}$ \\
\hline H1P2 (40 ml/l dan 73 hst) & 3671,333 & $\mathrm{k}$ \\
\hline H1P0 (40 ml/l dan tanpa pemangkasan) & 3583,000 & 1 \\
\hline H0P3 (0 ml/l dan $93 \mathrm{hst})$ & 3520,000 & $\mathrm{~m}$ \\
\hline H3P0 (120ml/l dan tanpa pemangkasan) & 3472,667 & $\mathrm{n}$ \\
\hline HOP0 (0 ml/l dan tanpa pemangkasan) & 3432,333 & o \\
\hline H3P1 (120 ml/l dan 53 hst) & 3183,333 & $\mathrm{p}$ \\
\hline
\end{tabular}

Keterangan : Angka yang diikuti huruf yang sama pada kolom yang sama menunjukkan hasil yang berbeda tidak nyata berdasarkan Uji Duncan pada taraf 5\%.

Efektifitas interaksi konsentrasi pupuk hayati cair $80 \mathrm{ml} / \mathrm{l}$ air dan pemangkasan daun umur 73 hst (H2P2) terhadap interaksi tanpa perlakuan pupuk hayati cair dan tanpa pemangkasan daun (H0P0) sebesar 51\%

Jumlah buah per petak:

$$
=\frac{H 2 P 2-H 3 P 1}{H 2 P 2} \times 100 \%=\frac{4093,667-6181,667}{4093,667} \times 100 \%=51 \%
$$


Jika di konversikan dalam satuan ton/ha maka menggunakan rumus sebagai berikut . Konversi ha :

$$
=\frac{\text { Luas } 1 \mathrm{Ha}\left(\mathrm{m}^{2}\right)}{\operatorname{Luas} \operatorname{Lahan}\left(\mathrm{m}^{2}\right)} \times H 2 P 2=\frac{10.000}{2,5} \times 4093,667 \mathrm{~g}=16,37 \mathrm{ton} / \mathrm{Ha}
$$

\section{Panjang Buah Per Sampel}

Panjang buah per sampel setelah dianalisis sidik ragam pada perlakuan faktor konsentrasi pupuk cair hayati menunjukkan pengaruh yang berbeda sangat nyata, perlakuan pemangkasan daun, dan interaksi kedua faktor tersebut berpengaruh berbeda tidak nyata (Tabel 1).

Tabel 11. Rata-rata Panjang Buah Per Sampel Faktor Pupuk Cair Hayati (H)

\begin{tabular}{llc}
\hline Konsentrasi Pupuk Hayati Cair & \multicolumn{2}{c}{ Panjang Buah Per Sampel $(\mathrm{cm})$} \\
\hline H3 (120 ml/l air $)$ & 6,81365741 & $\mathrm{a}$ \\
H2 $(80 \mathrm{ml} / \mathrm{l}$ air $)$ & 6,80231481 & $\mathrm{a}$ \\
H1 $(40 \mathrm{ml} / \mathrm{l}$ air $)$ & 6,73263889 & $\mathrm{~b}$ \\
H0 $(0 \mathrm{ml} / \mathrm{l}$ air $)$ & 6,60416667 & $\mathrm{c}$ \\
\hline
\end{tabular}

Keterangan: Angka yang diikuti huruf yang sama pada kolom yang sama menunjukkan hasil yang berbeda tidak nyata berdasarkan Uji Duncan pada taraf 5\%.

Panjang buah per sampel yang terpanjang diperoleh dari perlakuan konsentrasi 120 $\mathrm{ml} / \mathrm{l}$ air (H3) dibandingkan dengan kontrol (H0). Untuk rata-rata panjang buah per sampel terpanjang yaitu $6,8 \mathrm{~cm}$ dan yang terpendek yaitu $6,6 \mathrm{~cm}$ (Tabel 11).

Tabel 12. Panjang buah per petak pada faktor pemangkasan daun (P)

\begin{tabular}{lcl}
\hline Pemangkasan Daun & Panjang Buah Per Sampel $(\mathrm{cm})$ \\
\hline P2 (pemangkasan daun 73 hst) & 6,760 & a \\
P1 (pemangkasan daun 53 hst) & 6,756 & a \\
P3 (pemangkasan daun 93 hst) & 6,738 & a \\
P0 (tanpa pemangkasan daun) & 6,697 & $\mathrm{~b}$ \\
\hline
\end{tabular}

Keterangan: Angka yang diikuti huruf yang sama pada kolom yang sama menunjukkan hasil yang berbeda tidak nyata berdasarkan Uji Duncan pada taraf 5\%.

Panjang buah per petak berdasarkan Tabel 12 menunjukan bahwa perlakuan pemangkasan daun pada umur 93 hst (P3) cenderung memberikan rata-rata panjang buah per sampel yang tertinggi dibandingkan dengan umur pemangkasan lainnya. Hal ini dikarenakan pemangkasan daun berperan positif dalam laju fotosintesis yang mengakibatkan buah okra menjadi panjang. 
Tabel 13. Panjang buah per petak pada faktor interaksi antara konsentrasi pupuk hayati cair dan pemangkasan daun $(\mathrm{HxP})$

\begin{tabular}{|c|c|}
\hline Interaksi Pupuk Hayati Cair dan Pemangkasan Daun & Panjang Buah Per Petak $(\mathrm{cm})$ \\
\hline H3P2 (120 ml dan 73 hst) & $6,846 \quad \mathrm{a}$ \\
\hline H3P1 (120 ml/l dan 53 hst) & 6,828 \\
\hline H2P1 (80 ml/l dan 53 hst) & 6,822 \\
\hline H1P0 (40 ml/l dan tanpa pemangkasan) & 6,819 \\
\hline H2P3 (80 ml/l dan 93 hst) & 6,818 \\
\hline H2P2 (80 ml dan $73 \mathrm{hst}$ ) & 6,814 \\
\hline H3P0 (120ml/l dan tanpa pemangkasan) & 6,811 \\
\hline H3P3 (120 ml/l dan 93 hst) & 6,769 \\
\hline H2P0 (80 ml/l dan tanpa pemangkasan) & 6,756 \\
\hline H1P3 (40 ml/l dan 93 hst) & 6,706 \\
\hline H1P1 (40 ml/l dan 53 hst) & 6,703 \\
\hline H1P2 (40 ml/l dan $73 \mathrm{hst})$ & 6,703 \\
\hline H0P2 (0 ml/l dan 73 hst $)$ & 6,681 \\
\hline H0P1 (0 ml/1 dan 53 hst $)$ & 6,672 \\
\hline H0P3 (0 ml/l dan 93 hst $)$ & 6,661 \\
\hline H0P0 (0 ml/l dan tanpa pemangkasan) & 6,403 \\
\hline
\end{tabular}

Keterangan: Angka yang diikuti huruf yang sama pada kolom yang sama menunjukkan hasil yang berbeda tidak nyata berdasarkan Uji Duncan pada taraf 5\%.

Panjang buahper petak berdasarkan hasil analisis sidik ragam menunjukkan bahwa faktor interaksi pupuk hayati cair pada konsentrasi $120 \mathrm{ml} / \mathrm{l}$ air dengan pemangkasan daun 53 hst (H3P2) memberikan hasil yang terbaik dengan panjang buah per petak yaitu sepanjang $6,85 \mathrm{~cm}$.

\section{Warna Buah}

Warna buah okra setelah dilakukan analisis deskriptif menunjukkan bahwa pada perlakuan konsentrasi pupuk hayati cair dengan pemangkasan daun berbagai umur. Warna efektif yang dikehendaki oleh konsumen apabila warna buah okra mulai pemetikan pertama sampai dengan pemetikan terakhir dapat mempertahankan warna hijau pinur (kode 007520), disusul secara berurutan hijau lumut (kode 336600), hijau basil (kode 369900), dan hijau pir (kode 518413).

Warna buah okra diperoleh pada interaksi perlakuan antara faktor konsentrasi pupuk hayati cair dan pemangkasan daun pada umur 63 hst menunjukkan bahwa rata-rata dari kedua faktor interaksi didominasi oleh hijau basil dengan jumlah 45 buah, sedangkan selebihnya berwarna hijau lumut dengan jumlah 5 buah.

Warna buah okra diperoleh pada interaksi perlakuan antara faktor konsentrasi pupuk hayati cair dan pemangkasan daunpada umur 103 hst menunjukkan bahwa rata-rata dari kedua faktor interaksi didominasi oleh hijau pir sebanyak 27 buah, hijau basil dengan jumlah 14 buah, dan selebihnya berwarna hijau lumut sebanyak 7 buah.

Warna buah pada faktor pupuk hayati cair berbagai konsentrasi dan pemangkasan daunpada umur 83 hst menunjukkan bahwa warna buah didominasi oleh hijau basil dengan jumlah 40 buah, sedangkan selebihnya berwarna hijau lumut sebanyak 10 buah. 


\section{KESIMPULAN DAN SARAN}

\section{Kesimpulan}

Berdasarkan hasil penelitian tentang efektifitas konsentrasi pupuk hayati cair dan pemangkasan daun terhadap produksi okra, maka dapat disimpulkan sebagai berikut :

1) Efektifitas konsentrasi pupuk hayati cair terhadap produksi okra:

a. Jumlah buah per sampel terbanyak sebesar 62 buah pada konsentrasi $120 \mathrm{ml} / \mathrm{l}$ air dapat meningkatkan produksi $1 \%$ dan terhadap jumlah buah per petak terbanyak sebesar 644 buah pada konsentrasi $80 \mathrm{ml} / \mathrm{l}$ air dapat meningkatkan produksi $7 \%$.

b. Berat buah petak terbanyak sebesar 3867,00 gram pada konsentrasi $80 \mathrm{~m} / \mathrm{l}$ air dapat meningkatkan produksi $9 \%$.

2) Efektifitas pemangkasan daun terhadap produksi okra:

a. Jumlah buah per sampel terbanyak sebesar 61 buah pada umur 93 hst dapat meningkatkan produksi $1 \%$ dan terhadap jumlah buah per petak terbanyak sebesar 633 pada umur 93 hst dapat meningkatkan hasil produksi $6 \%$.

b. Berat buah per sampel terbanyak sebesar 3795,42 gram pada umur 73 hst dapat meningkatkan produksi $6 \%$.

3) Efektifitas interaksi konsentrasipupuk hayati cair dan umur pemangkasan daun terhadap produksi okra:

a. Jumlah buah per sampel terbanyak sebesar 63 buah pada interaksi tanpa pupuk hayati cair dan tanpa pemangkasan daun dapat meningkatkan produksi $3 \%$ dan terhadap jumlah buah per petak terbanyak sebesar 677 buahpada interaksi pupuk hayati cair konsentrasi $80 \mathrm{ml} / \mathrm{l}$ air dengan pemangkasan daun umur 73 hst dapat meningkatkan hasil produksi $21 \%$.

b. Berat buah per petak terbanyak sebesar 4093,67 gram (konversi 16,37 ton/ha) pada interaksi pupuk hayati cair konsentrasi $80 \mathrm{ml} / \mathrm{l}$ air dengan pemangkasan daun umur 73 hst dapat meningkatkan produksi $51 \%$.

4) Efektifitas interaksi konsentrasi pupuk hayati cair dan umur pemangkasan daun terhadap panjang buah okra per sampel:

Panjang buah okra per sampel yang dipengaruhi oleh pupuk hayati cair pada konsentrasi $120 \mathrm{ml} / \mathrm{l}$ air dengan panjang $6,81 \mathrm{~cm}$, yang dipengaruhi pemangkasan daun pada umur 73 hst dengan panjang $6,76 \mathrm{~cm}$, dan yang dipengaruhi oleh interaksi antara pupuk hayati cair pada konsentrasi $120 \mathrm{ml} / \mathrm{l}$ air dengan pemangkasan daun pada umur 73 hst dengan panjang $6,85 \mathrm{~cm}$.

5) Efektifitas interaksi beberapa konsentrasi perlakuan pupuk hayati cair dan umur pemangkasan daun terhadap warna buah okra per sampel:

a. Warna buah okra per sampel yang dipengaruhi oleh interaksi antara pupuk hayati cair pada beberapa konsentrasi perlakuan $(0,40,80$, dan $120 \mathrm{ml} / \mathrm{l}$ air) dengan pemangkasan daun pada umur 63 hst didominasi oleh warna hijau basil sejumlah 45 buah dan hijau lumut sebanyak 5 buah.

b. Warna buah okra per sampel yang dipengaruhi oleh interaksi antara pupuk hayati cair pada beberapa konsentrasi perlakuan $(0,40,80$, dan $120 \mathrm{ml} / \mathrm{l}$ air) dengan 
pemangkasan daun pada umur 83 hst didominasi oleh warna hijau basil sejumlah 40 buah dan hijau lumut sebanyak 10 buah.

c. Warna buah okra per sampel yang dipengaruhi oleh interaksi antara pupuk hayati cair pada beberapa konsentrasi perlakuan $(0,40,80$, dan $120 \mathrm{ml} / \mathrm{l}$ air) dengan pemangkasan daun pada umur 103 hst didominasi oleh warna hijau pir sejumlah 27 buah, hijau basil 14 buah, dan hijau lumut sebanyak 7 buah.

\section{Saran}

Penanaman okra dianjurkan menggunakan konsentrasi pupuk hayati cair pada konsntrasi 80 $\mathrm{ml} / \mathrm{l}$ air dengan pemangkasan daun pada umur $73 \mathrm{hst}$

\section{DAFTAR PUSTAKA}

Darmawan dan J. Baharsyah. 1983. Dasar-dasar Fisiologi Tanaman. Suryandara Utama, Semarang. $89 \mathrm{hlm}$.

Dwijosepoetro, D. 1996. Pengantar Fisiologi Tumbuhan. Gramedia, Jakarta.

Gardner, P.F,B.R. Pearce, dan L.R.Mitchell, 1991. Fisiologi Tanaman Budidaya. Universitas Indonesia Press, Jakarta.

Manuhuttu, A. P., H. Rehatta, dan J. J. G. Kailola. 2014. Pengaruh Konsentrasi Pupuk Hayati Bioboost terhadap Peningkatan Produksi Tanaman Selada (Lactuca sativa. L.). Agrologia. 3 (1): 18-27.

Palimbungan N., R. Labatar, dan F. Hamzah F. 2006. Pengaruh ekstrak daun lamtoro sebagai pupuk organik cair terhadap petumbuhan dan produksi tanaman sawi. J. Agrisistem Vol 2 (2): $96-101$.

Parman, S. 2007. Pengaruh Pemberian Pupuk Organik Cair Terhadap Pertumbuhan dan Produksi Kentang (Solanum tuberosum L.). Buletin Anatomi dan Fisiologi 15(2): 21-31.

Suwarno, V. S. 2013. Respon pertumbuhan dan produksi tanaman mentimun (Cucumis sativus L.) melalui perlakuan pupuk NPK pelangi. Jurnal Karya Ilmiah Mahasiswa Universitas Negeri Gorontalo. 1(1): 1-12.

Urgel, E.M., A Salido, dan J. Ramos, 2000. Genetic Analysis Of Function Involved In Adhesion Of Pseudomonas Putida To Seed. Journal Of Bacteriology, 182.P.23632369.

Widyastuti, N. dan D. Tjokrokusumo. 2007. Peranan beberapa zat pengatur tumbuh (zpt) tanaman pada kultur in vitro. Jurnal Sains dan Teknologi Indonesia, Jakarta. 3 (5):55-63.

William, D., A. Teale, I. Paponov and K. Palme. 2006 Auxin in action: signalling, transport and the control of plant growth and development Nature Reviews. Molecular Cell Biology. Nature Publishing Group. 7: 847-859

Winarso, S. 2005. Kesuburan Tanah Dasar Kesehatan dan Kualitas Tanah. Gava Media, Yogyakarta. 